\title{
Materializm i wychowanie w myśli Alexisa de Tocqueville'a
}

\author{
Łukasz Mirocha \\ (Uniwersytet Mikołaja Kopernika w Toruniu, Wydział Prawa i Administracji)
}

\section{Wprowadzenie}

„Materializm” funkcjonuje w myśli Alexisa de Tocqueville’a w co najmniej dwóch znaczeniach. Z pierwszego $\mathrm{z}$ nich francuski filozof korzysta, mówiąc na przykład o „materialistycznej teorii”, w myśl której „surowość obyczajów kobiet jest zależna od położenia ich kraju względem równika"', czy komentując rasowe teorie Artura de Gobineau w korespondencji z nim². Tak rozumiany materializm to pogląd ontologiczny głoszący, że istnieje wyłącznie materia i to ona - lub jej zmiany - są czynnikiem sprawczym także w zakresie zjawisk społecznych. Komentowany autor zajmuje krytyczne stanowisko względem materializmu pojmowanego w ten sposób. Materializm w drugim znaczeniu to postawa, zgodnie $\mathrm{z}$ którą dobra materialne odgrywają w życiu człowieka wiodącą rolę. Tocqueville odnosi się do tego znaczenia, mówiąc o „upodobaniu luksusu”, „poszukiwaniu dóbr materialnych”, „miłości pieniądza” czy „niespokojnej i żarliwej namiętności” do dobrobytu ${ }^{3}$. Praca dotyczy drugiego ze wskazanych znaczeń materializmu.

1 A. de Tocqueville, O demokracji $w$ Ameryce, tłum. M. Król, Państwowy Instytut Wydawniczy, Warszawa 1976, s. 386.

2 List do Artura de Gobineau z 17.11.1853 r., w: A. de Tocqueville, Listy, tłum. B. Janicka, Społeczny Instytut Wydawniczy Znak, Kraków 1999, s. 279.

3 A. de Tocqueville, O demokracji..., dz. cyt., kolejno s. 29, 57, 64, 211. 
Jeśli uznamy komentowaną postawę za problematyczną, konieczne wyda się poszukiwanie środków zaradczych. We współczesnych naukach społecznych coraz częściej dostrzega się negatywny wpływ materializmu na jednostkę czy społeczeństwo. Jako rozwiązanie proponuje się raczej miękkie metody oddziaływania (takie jak wpajanie odpowiednich postaw), niż zdecydowane działania w postaci norm prawnych ${ }^{4}$ (abstrahując od kwestii wychowawczej funkcji norm). Nie może zatem dziwić, że materializm, czy będący jego wyrazem konsumpcjonizm, są przedmiotem zainteresowania nie tylko ekonomistów ${ }^{5}$, lecz także pedagogów ${ }^{6}$.

Zaryzykować można twierdzenie, że badacze upatrujący w wychowaniu środka mającego zapobiegać rozwojowi postaw materialistycznych i chronić przed nim podążają drogą wytyczoną przez Alexisa de Tocqueville’a. Mimo że był on prawnikiem z wykształcenia i - częściowo - wykonywanej profesji, miał świadomość, że prawo nie jest wystarczającym instrumentem zapobiegania negatywnym zjawiskom społecznym. Paweł Marczewski, opisując stanowisko francuskiego myśliciela, mówi o „komplementarności cnoty i praw”" w jego rozważaniach; koncepcję demokracji budowaną przez Tocqueville’a nazywa się „kulturalistyczną" właśnie z uwagi na włączenie do niej nie tylko wątków prawno-ustrojowych, lecz także tych dotyczących „układu społecznego”, obyczajów, religii.

Francuski myśliciel wielokrotnie daje wyraz świadomości ograniczonej mocy prawa i jego wychowawczego wpływu. Pisze o tym, że w Europie: „Zbyt wielkie znaczenie przypisuje się również prawom, zbyt małe - obyczajom"9, co kontrastuje z podejściem Amerykanów. $\mathrm{Z}$ potępieniem wypowiada się o zaczerpnięciu inspiracji z Pisma Świętego przez ustawodawcę Connecticut tworzącego w 1650 roku stanowy kodeks karny ${ }^{10}$. Dostrzega on więc nieprzystawalność surowego

4 Jako wyjątek od tej reguły można traktować np. zakaz handlu w niedzielę czy obowiązujące w antycznym Rzymie tzw. leges sumptuariae.

5 Tim Jackson mówi o „żelaznej klatce konsumpcjonizmu” (tenże, Dobrobyt bez wzrostu. Ekonomia dla planety o ograniczonych możliwościach, tłum. M. Polakowski, Wydawnictwo Naukowe UMK, Toruń 2015, s. 115 i n.)

6 K. Starego, Projekt: Obywatel. Rzecz o społecznej kontroli, zarządzaniu zmysłowością i strategiach oczyszczania, w: Subsumcje edukacji, red. M. Chutorański, J. Moroz, O. Szwabowski, Wydawnictwo Naukowe Katedra, Gdańsk 2017, s. 215 i n.

7 P. Marczewski, Uczynić wolność nieuchronną. Wątki republikańskie w myśli Alexisa de Tocqueville’a, Wydawnictwo IFiS PAN, Warszawa 2012, s. 119.

8 S. Bykowska, Wspólnota obywateli w idei demokracji Alexisa de Tocquevilléa. Ameryka wzorem dla Europy, „Studia Gdańskie. Wizje i rzeczywistość” 2010, t. VII, s. 190.

9 A. de Tocqueville, $O$ demokracji..., dz. cyt., s. 221.

10 Tamże, s. 53. 
karania za występki moralne do realiów XVII-wiecznej kolonii, ale też fakt, że są sfery życia społecznego, które nie powinny być przedmiotem zainteresowania prawa. Inną ilustracją tego, że w optyce Francuza kontekst kulturowy ma co najmniej takie samo znaczenie, co treść prawa, jest słaby efekt przeszczepienia treści amerykańskiej Konstytucji przez meksykańskiego ustrojodawcę: „przenosząc do siebie literę prawa nie zdołali jednocześnie przenieść jego ducha"11.

Artykuł ma na celu przedstawienie stosunku Tocqueville’a do materializmu (w drugiej części tekstu, gdzie zaprezentowany jest kontekst społeczny tego zjawiska, wyjaśniona zostaje jego istota oraz negatywne konsekwencje) oraz zaprezentowanie preferowanych przez francuskiego filozofa środków zapobiegających tej postawie. Część trzecia tekstu obejmuje znaczenie edukacji formalnej, etyki cnót oraz religii w analizowanym kontekście. Wydaje się, że w tym zakresie Francuz demonstruje swoje profetyczne zdolności ${ }^{12}$ nie tylko w wymiarze diagnostycznym - prawidłowo przepowiadając zdominowanie społeczeństw demokratycznych przez materializm, lecz także - przynajmniej częściowo - w wymiarze sanacyjnym, opisując nadal aktualne metody walki z materializmem, które można zbiorczo nazwać wychowaniem.

\section{Materializm}

\subsection{Kontekst społeczny: demokracja, równość możliwości, wpływ klasy średniej}

Tocqueville przyjmuje w swoim pisarstwie metodę komparatystyczną. Mówiąc o Ameryce, porównuje ją do rodzimej Francji. Komentując życie amerykańskich kolonistów, zestawia je z losami metropolii - Anglii. Czasy porewolucyjne we Francji konfrontuje $\mathrm{z}$ „dawnymi rządami”. Punktem odniesienia dla demokracji jest arystokracja. Analizy Francuza są głębokie, nie sprowadzają się do opisu instytucji, lecz prowadzą do odkrycia rzeczywistych przyczyn komentowanych przez niego zjawisk. Wydaje się, że właśnie temu służy wskazana metoda. Rów-

11 Tamże, s. 128.

12 Odnośnie do prognostycznych zdolności Francuza panuje swego rodzaju communis opinio, są jednak kwestie, w których jego przewidywania się nie potwierdziły, zob. J. Baszkiewicz, Wstęp, w: A. de Tocqueville, O demokracji..., dz. cyt., s. 16-18; D. Choi, Unprophetic Tocqueville. How Democracy in America Got the Modern World Completely Wrong, „The Independent Review” 2007, Vol. XII, No. 2, s. 165-178. 
nież dlatego, przed zaprezentowaniem znaczenia materializmu obecnego w myśli francuskiego filozofa, konieczne jest ukazanie kontekstu, w jakim rozwija się postawa materialistyczna.

Ma to miejsce w warunkach demokracji, przy czym zasadniczym jej rysem nie jest dla Tocqueville’a „ludowładztwo”, lecz panująca pomiędzy obywatelami równość. Francuz pisze o „równości możliwości”, co mogłoby przywodzić na myśl równość formalną, a nie substancjalną; równość taka jest w pierwszej kolejności „równością szans”"13 nie zaś „równością efektów”. Opisywana przez niego równość nie obejmuje oczywiście czarnoskórej ludności Ameryki, w wymiarze politycznym nie dotyczy kobiet, które jednak w pozostałych aspektach życia mają znacznie szersze możliwości niż w ustroju arystokratycznym. Źródłem tak pojmowanej równości jest to, że „wszyscy ludzie zostają uznani za jednakowo światłych, cnotliwych i silnych"14.

Założenie to prowadzi jednak dalej niż do formalnych gwarancji równości, przynosząc faktycznie egalitaryzujący efekt we wszystkich aspektach życia społecznego. Jak pisze Tocqueville: „następstwa tego faktu wykraczają daleko poza domenę obyczajów politycznych i praw [...] w równym stopniu wpływają na cywilną społeczność i na rząd: kształtują poglądy, rodzą emocje, podpowiadają praktyczne rozwiązania oraz zmieniają wszystko, co nie jest ich własnym dziełem"15. Stany Zjednoczone opisane przez Tocqueville’a są społeczeństwem "bez wielkich panów i bez ludu oraz właściwie bez biednych i bez bogatych"16, bowiem „Począwszy od tej chwili wszystkie nowe zjawiska, wszystkie powstające potrzeby, wszystkie pragnienia domagające się zadośćuczynienia stały się stopniami wiodącymi ku powszechnemu zrównaniu. Upodobanie do luksusu, zamiłowanie do wojny, dyktat mody, najbłahsze i najgłębsze namiętności ludzkiego serca zgodnie pracowały nad zubożeniem bogatych i wzbogaceniem biednych"17.

Jeśli pozytywnym skutkiem funkcjonowania równości możliwości jest egalitaryzm, to jego kosztem jest przeciętność w niemal wszystkich aspektach życia. Podobne obserwacje poczyni niecałe stulecie później José Ortega y Gasset, formułując swój słynny manifest Bunt mas. Autor ten postawił tezę, że: „umysły

13 Zob. A. Plichta, Równość i demokracja w myśli Alexisa de Tocqueville’a, „Acta Erasmiana” 2013, t. V, s. 265.

14 A. de Tocqueville, $O$ demokracji..., dz. cyt., s. 74.

15 Tamże, s. 27.

16 Tamże, s. 51.

17 Tamże, s. 29. 
przeciętne i banalne, wiedząc o swej przeciętności i banalności, mają czelność domagać się prawa do bycia przeciętnymi i banalnymi i do narzucania tych cech wszystkim innym", a odnosząc się wprost do Stanów Zjednoczonych potwierdził intuicje Tocqueville’a: „W Ameryce Północnej powiada się: być innym to być nieprzyzwoitym"18. Wątek ten zostanie rozwinięty w kolejnych częściach pracy. W tym miejscu wskazać trzeba, że zdaniem francuskiego filozofa dążenie do równości i demokratyzacja są nieuchronne, nieuniknione ${ }^{19}$. Mimo to nie wszędzie istnieją warunki sprzyjające powstaniu równości. Tocqueville przekonuje, że można ją znaleźć „na dwóch przeciwległych krańcach cywilizacji” pojmowanej jednak nie jako obszar, lecz jako oś z brakiem cywilizacji na jednym krańcu i ucywilizowaniem na drugim. Równość panuje u dzikich (Francuz ma na myśli współczesnych mu Indian oraz historycznie: ludzkość prerolniczą), może także pojawić się wśród ludzi bardzo cywilizowanych. Pomiędzy tymi dwoma stanami panuje „nierówność kondycji, bogactwo, wykształcenie, władza jednych, ubóstwo, ignorancja i słabość wszystkich innych" ${ }^{20}$. Aspektem równości znajdującym uznanie w oczach komentowanego autora jest jej stabilizujący wpływ na społeczeństwo ${ }^{21}$.

Demokracja tworzy według francuskiego myśliciela środowisko rozwoju postawy materialistycznej, jednak jej matecznik jest zidentyfikowany o wiele precyzyjniej. Jest nim klasa średnia. Już na stronach $O$ demokracji w Ameryce Tocqueville łączy ją z komentowanym w tej pracy problemem: „Jeżeli uważnie przyjrzymy się każdej spośród klas społecznych, zauważymy, że namiętność posiadania jest szczególnie zachłanna i uporczywa w klasach średnich" ${ }^{22}$. Biedota nie troszczy się szczególnie o własność, ponieważ zmaga się z bardziej palącymi problemami, $z$ kolei na bogatych posiadanie nie robi już takiego wrażenia. To klasa średnia jest najbardziej zainteresowana posiadaniem, wynika z tego jej podejście do kwestii podatkowych czy nagłych zmian ustroju społecznego (rewolucji). Komentowany autor przypuszcza właściwy atak na klasę średnią dopiero w swoich Wspomnieniach. Pozornie pozytywne jej cechy, takie jak przedsiębiorczość, duch aktywności czy umiarkowanie, przysłania jego zdaniem ,upodobanie w do-

\footnotetext{
18 J. Ortega y Gasset, Bunt mas, przeł. P. Niklewicz, Wydawnictwo Replika, Zakrzewo 2016, s. 19.

19 J. Baszkiewicz, Wstęp, dz. cyt., s. 7.

20 A. de Tocqueville, Raport o pauperyzmie, przeł. J. Strzelecka, Wydawnictwo Uniwersytetu Warszawskiego, Warszawa 2009, s. 44.

21 A. de Tocqueville, O demokracji..., dz. cyt., s. 389-390.

22 Tamże, s. 427.
} 
brobycie” i egoizm, co daje rządy „pozbawione wielkości i cnoty”23. Tocqueville upatruje w klasie średniej sprawcy rewolucji lipcowej (1830 roku) i przypisuje jej sprawowanie rządów po niej następujących przy pomocy korupcji (pojmowanej właśnie jako wpojenie społeczeństwu przekonania o tym, że dobra materialne są najistotniejsze), a nie ucisku czy przemocy ${ }^{24}$. Wyraźny jest więc wpływ materializmu na sferę polityczną. Klasa średnia jawi się w rozważaniach Tocqueville’a jako pozbawiona zdolności autorefleksji (w przeciwieństwie do arystokracji), niechętna braniu odpowiedzialności za własne przewinienia ${ }^{25}$. Powyższe spostrzeżenia są o tyle ważne, że „w społeczeństwach demokratycznych warstwa ludzi średnio zamożnych jest warstwą kształtującą idee i obyczaje. Wszystkim narzuca swoje poglądy oraz wolę i nawet ci, którzy najbardziej skłonni są opierać się jej przewodnictwu, idą w końcu za jej przykładem"26. Paweł Śpiewak, podsumowując stosunek Francuza do klasy średniej, pisze:

Klasę średnią stać tylko na stworzenie ustroju małych idei i ograniczonych, hałaśliwych pragnień. Tocqueville docenia siłę burżuazji, ale nie ceni jej idei, dostrzega jej sprawność, ale ma ją za klasę chciwców - opisuje ją sardonicznym, kpiącym tonem, tworząc obraz bliski karykaturze. [...] Z pewnością nie ukrywa odrazy, niemal wstrętu, za którym czasem można odkryć jego klasowe przesądy ${ }^{27}$.

Wartym wspomnienia aspektem kontekstu społecznego, w którym rodzi się postawa materialistyczna, jest stosunek ludzi demokracji do czasu. Tocqueville dostrzega ich „skłonność do łatwych sukcesów i doraźnych zaspokojeń”, pisze, że „Większością ludzi żyjących w czasach równości rządzą gwałtowne, lecz wątłe ambicje”28. Współczesne nauki społeczne nazywają to podejście „wysoką preferencją czasową", co oznacza przedkładanie dóbr teraźniejszych nad większe, lecz późniejsze, wiąże się z niską skłonnością do oszczędzania oraz wysoką chęcią

\footnotetext{
23 A. de Tocqueville, Wspomnienia, tłum. A.W. Labuda, Wydawnictwo Zakład Narodowy im. Ossolińskich, Wrocław 1987, s. 5.

24 Tamże, s. 85, 88.

25 Tamże, s. 49.

26 Tenże, $O$ demokracji..., dz. cyt., s. 378.

27 P. Śpiewak, Alexis de Tocqueville: demokracja, rewolucje, socjalizm, w: A. de Tocqueville, Raport o pauperyzmie, dz. cyt., s. 15.

28 A. de Tocqueville, O demokracji..., dz. cyt., s. 282.
} 
natychmiastowej konsumpcji ${ }^{29}$. Wydaje się, że nawiązując do słynnej sentencji Edmunda Burke’a, Tocqueville notuje, że „demokracja nie tylko każe ludziom zapominać o przodkach, ale również pozbawia ich myśli o potomkach i odsuwa ich od współczesnych” ${ }^{30}$. W innym miejscu - komentując słabo zaludnione „pustkowia” Stanów Zjednoczonych - stwierdza on, że „nie obudziła się tam jeszcze idea przeszłości ani przyszłości”31. Trudno kłócić się z twierdzeniem, że podejście „liczy się tylko tu i teraz”, sprzyja materializmowi.

\subsection{Istota zjawiska}

Dziesiąty rozdział drugiego tomu O demokracji $w$ Ameryce (pt. O zamiłowaniu Amerykanów do materialnego dobrobytu) otwiera passus:

Namiętność do dobrobytu nie jest w Ameryce namiętnością jedyną, lecz powszechną, i jeżeli nawet nie u wszystkich jednakowo się objawia, żywią ją wszyscy. Umysł Amerykanów bez reszty pochłaniają zabiegi zmierzające do zaspokojenia wszystkich potrzeb ciała i wprowadzanie drobnych udogodnień życiowych ${ }^{32}$.

Passus ten oddaje Tocqueville'owskie rozumienie materializmu. Po pierwsze, obrazuje on język, którym Francuz posługuje się, mówiąc o materializmie - jest to język uczuć, emocji, namiętności. W innych miejscach Tocqueville pisze o „pragnieniu dobrobytu”, „żarliwej namiętności”33, „miłości pieniądza” ", „pasji bogactwa” 35 , „instynktach"36, "gorączce używania dóbr materialnych” ${ }^{37}$. Nie są to sformułowania zaczerpnięte ze słownika ekonomii; nie mają nic wspólnego z tym, co współcześnie próbuje się ubrać w garnitur „racjonalnego wyboru”. Tocqueville prawdopodobnie nie znał prac Marksa ${ }^{38}$ próbującego zjawiska

29 A. Radkowski, Co Tocqueville mówi nam o demokracji - spojrzenie z perspektywy ekonomicznej teorii polityki, „Societas et Ius” 2017, nr 6, s. 170.

30 A. de Tocqueville, $O$ demokracji..., dz. cyt., s. 340.

31 Tenże, Piętnaście dni w pustkowiu, tłum. R. Chymkowski, Polityka - Spółdzielnia Pracy, Warszawa 2003 , s. 45.

32 A. de Tocqueville, O demokracji $w$ Ameryce, dz. cyt., s. 354.

33 Tamże, s. 211.

34 Tamże, s. 64.

35 Tamże, s. 412.

36 Tamże, s. 421.

37 Tenże, Wspomnienia, dz. cyt., s. 75.

38 Zob. P. Śpiewak, Alexis de Tocqueville: demokracja..., dz. cyt., s. 23. 
ekonomiczne opisać językiem naukowym, znał jednak prace Adama Smitha, Jeremy'ego Benthama czy Thomasa Malthusa. Jest raczej pewne, że opisywanie komentowanego zjawiska w kategoriach uczuć czy emocji nie wynikało z braków $\mathrm{w}$ aparacie pojęciowym francuskiego autora, lecz było zabiegiem celowym, ale też - jak pokazują współczesne badania - trafnym. Brytyjski ekonomista Tim Jackson przekonuje, że „Artefakty konsumpcyjne odgrywają w naszym życiu rolę dalece wykraczającą poza ich funkcjonalność materialną”, a „[n]asze przywiązanie do rzeczy materialnych może być niekiedy tak silne, że doświadczamy poczucia osamotnienia i straty, gdy je tracimy"39. Głos Jacksona nie jest odosobniony - wykształcony w społeczeństwie imperatyw nabywania dóbr materialnych nie ma racjonalnych podstaw, co dostrzegł francuski myśliciel.

Drugi aspekt materializmu, który da się wyczytać z przytoczonego cytatu, to upowszechnianie się komentowanego zjawiska. Według Tocqueville’a zamiłowanie do bogactwa rodzi się w klasie średniej, ale szybko przenosi się na inne grupy społeczne. Opowiadanie Piętnaście dni w pustkowiu zawiera opis domostwa ubogich pionierów, według którego: „Zazwyczaj jest w takiej chacie tylko jedno okno, w którym czasem wisi firanka z muślinu; wszak tam, gdzie nierzadko brakuje rzeczy niezbędnych, często jest miejsce na zbytek" ${ }^{\prime 40}$. Wspomnienia Francuza w wielu miejscach traktują o zarażeniu warstwy robotniczej namiętnością do dobrobytu, jednak w najbardziej barwny sposób zjawisko to ilustruje anegdota o tym, jak służący jednego z przyjaciół Tocqueville’a na wieść o wybuchu rewolucji zapowiadali, że „W przyszłą niedzielę (był to czwartek), to już my będziemy jedli skrzydełka od kury” oraz „będziemy nosić ładne sukienki z jedwabiu"41.

Upowszechnieniu materializmu sprzyja swego rodzaju mechanizm równi pochyłej. Komentowany autor stwierdza, że „[p]ragnienie dobrobytu stało się u nich niespokojną i żarliwą namiętnością, która rośnie w miarę zaspokajania"”2. Mechanizm ten był wykorzystywany przez białych osadników w relacjach z Indianami. Oferowano im osiągnięcia ówczesnej techniki - broń palną, alkohol, tkaniny, bez których Indianie radzili sobie wcześniej, jednak w momencie przywyknięcia do nich, zaczęły być one traktowane jako potrzeba. Jej zaspokoje-

\footnotetext{
T. Jackson, Dobrobyt..., dz. cyt., s. 128.

A. de Tocqueville, Piętnaście dni..., dz. cyt., s. 18.

Tenże, Wspomnienia, dz. cyt., s. 170.

Tenże, O demokracji..., dz. cyt., s. 211.
} 
niem mogli trudnić się tylko biali w ramach nieuczciwego handlu ${ }^{43}$. Zjawisko przyzwyczajania się do zbytków, które jeszcze chwilę wcześniej traktowane były jako „dobrodziejstwo losu”, opisuje również Ortega y Gasset. W jego obserwacjach zjawisko to rozwija się według logiki podobnej do tej przedstawionej przez Tocqueville’a we Wspomnieniach - dostęp do zbytków zaczyna być postrzegany przez masy jako uprawnienie ${ }^{44}$.

Trzecim elementem definicji materializmu, dającym się wyczytać z fragmentu otwierającego dziesiąty rozdział drugiego tomu O demokracji w Amery$c e$, jest relacja materializmu i ludzkich potrzeb. Dostrzegalne na pierwszy rzut oka jest to, że materializm odnosi się do potrzeb cielesnych, a nie duchowych ${ }^{45}$. Precyzyjniejszego opisu rozwoju ludzkich potrzeb, prowadzącego ostatecznie do powstania mechanizmu sztucznego ich kreowania, dostarcza Raport o paupery$z m i e$. Francuz wyraźnie rozdziela w nim potrzeby pierwszego rzędu - naturalne, fizyczne, podobne zwierzęcym, i te drugorzędne ${ }^{46}$. W pierwszej kategorii mieści się zapewnienie pożywienia, odzieży, schronienia, pozostałe są potrzebami - co istotne w perspektywie przedmiotu pracy - z którymi człowiek się nie rodzi, lecz je sobie stwarza, potrzebami wynikającymi ze „zwyczaju i wychowania” ${ }^{47}$. Podział na potrzeby prymarne i sekundarne nałożony zostaje przez Francuza na oś rozwoju historycznego. Pisze on, że człowiek w społeczeństwach pierwotnych oraz współcześni Tocqueville’owi Indianie, mieli niewielkie pragnienia, potrzeby. Potrzeby drugiego rzędu rosły wraz z dokonującymi się zmianami społeczno-gospodarczymi, po czym osiągnęły największe rozmiary współcześnie. Co istotne, na skutek tych zmian rosło również poczucie niezaspokojenia potrzeb: „U ludów wysoko cywilizowanych nędzę powoduje brak całego mnóstwa rzeczy; w stanie dzikości ubóstwo polega wyłącznie na braku pożywienia"48.

Materializm, z perspektywy Tocqueville’a zasługujący na potępienie, należy więc odróżnić od zaspokajania rzeczywistych potrzeb. Materializm może przy-

Tamże, s. 233.

44 J. Ortega y Gasset, Bunt mas, dz. cyt., s. 75.

45 Tocqueville przewiduje, że w razie opanowania umysłów większości ludzi wyłącznie przez żądze materialne, wśród niektórych nastąpiłaby reakcja w postaci poświęcenia się życiu duchowemu; „Byłbym zdumiony, gdyby w społeczeństwie oddanym bez reszty sprawie dobrobytu nie pojawił się niebawem i nie rozwijał mistycyzm" (O demokracji w Ameryce, s. 357).

46 Zob. M. Tracz-Tryniecki, Myśl polityczna i prawna Alexisa de Tocqueville, Księgarnia Akademicka, Kraków 2009, s. 212.

47 A. de Tocqueville, Raport o pauperyzmie, dz. cyt., s. 48.

48 Tamże, s. 49. 
brać różne formy: nabywania zbędnych dóbr, gromadzenia pieniędzy czy wartościowych przedmiotów, pogoni za zyskiem w handlu czy przemyśle, które nie spełniają kryterium obiektywnej potrzeby. Ilustracją tego rozróżnienia może być podejście Indian, o których Francuz pisze z uznaniem, że „uśmiechają się gorzko. widząc, jak miotamy się w życiu, żeby zdobyć niepotrzebne bogactwo" ${ }^{\prime 9}$. Dokonują oni wyborów, kierując się użytecznością przedmiotów, a nie estetycznymi konwencjami - indiański przewodnik Francuza obdarza największym zainteresowaniem należącą do niego nietłukącą się butelkę oraz broń ${ }^{50}$.

Postawa materialistyczna rzutuje na niemal wszystkie sfery życia. Tocqueville komentuje przykłady takiego wpływu na literaturę (efektem są dzieła masowe, sztampowe, służące uprzyjemnieniu życia), teatr (który ma dostarczyć tanich emocji, a nie refleksji - sztuki się wyłącznie ogląda, ale już ich nie czyta), a nawet naukę (która podporządkowana jest „potrzebom ciała”, a nie umysłu, co zdaniem Francuza miało miejsce w czasach arystokracji). Autor Piętnastu dni w pustkowiu dzieli się gorzką obserwacją, że zasiedlający Nowy Świat „handlują wszystkim bez wyjątku, nawet moralnością i religią"51. Jest on jednak daleki od przypisywania ludziom objętym materialistycznymi skłonnościami „duchowej niższości”, dostrzega on, że w demokracji pieniądz odgrywa rzeczywiście większą rolę niż wcześniej ${ }^{52}$. W tym kontekście zasadne wydaje się jednak pytanie o to, czy to rola pieniądza doprowadziła do materializmu, czy materializm do wzrostu roli pieniądza.

Materializm wywiera także niebagatelny wpływ na sferę polityczną. Tocqueville we Wspomnieniach pokazuje, jak namiętności rewolucyjne były „roztapiane w żądzy materialnego użycia" ${ }^{33}$. Jednakże komentowana postawa jest jego zdaniem groźna nie tylko w burzliwym okresie rewolucji. Jak pisze Krzysztof Kędziora, wynika to z faktu, że: „Demokratyczny materializm niszczy ludzką wolność, skłaniając ludzi do pogoni za materialnym dobrobytem i do wycofania z życia publicznego. Powoduje, że jedyną ludzką namiętnością jest pragnienie wygodnego życia i zaspokajania cielesnych przyjemności”"54.

\footnotetext{
49 A. de Tocqueville, Piętnaście dni..., dz. cyt., s. 48.

50 Tamże, s. 41.

51 Tamże, s. 20.

52 Tenże, $O$ demokracji..., dz. cyt., s. 406.

53 Tenże, Wspomnienia, dz. cyt., s. 77.

54 K. Kędziora, Alexis de Tocqueville o egzystencjalnym i społecznym znaczeniu religii, „Studia Philosophiae Christianae UKSW" 2014, nr 50/4, s. 49-50.
} 
Mimo to Francuz nie jest jednoznacznie krytyczny względem materializmu. Niuansuje on swoje stanowisko, dostrzegając na przykład różnicę w podejściu Amerykanów z kolonii południowych i tych z Nowej Anglii. Amerykanów z północy postrzega jako pracowitych, ambitnych, rozważnych, wykształconych. Południowcy z kolei zbliżają się do typu zasiedziałego arystokraty, który jest nawykły do luksusu, przyjemności, próżniactwa, wysługuje się niewolnikami ${ }^{55}$. Tocqueville zapewnia, że w kontraście do stanów północnych, w których osadnicy często poszukiwali wytchnienia duchowego, w odniesieniu do stanów południowych „ani jeden zamysł pozbawiony motywu korzyści materialnej nie przyświecał powstającym koloniom" ${ }^{26}$.

Opierając się na przykładzie Amerykanów zasiedlających Nową Anglię, Francuz dostrzega, że materializm może być akceleratorem ambicji i przedsiębiorczości. Może się on przekładać na rozwój przemysłu, zarówno ze względu na wzrost popytu ${ }^{57}$, jak i jego udoskonalanie motywowane chęcią zysku. Paweł Śpiewak interpretuje myśl Tocqueville’a w ten sposób, że namiętność do dobrobytu „porządkuje życie" ${ }^{58}$. Nie można nie zgodzić się z twierdzeniem, że dostarcza ona jasnego, zrozumiałego dla każdego i - w warunkach równości możliwości - przynajmniej dla każdego potencjalnie osiągalnego celu. Materializm ma więc walor porządkujący, co oczywiście nie oznacza, że Francuz nie dostrzega bardziej wartościowych mechanizmów tego porządkowania (np. religii, o czym w dalszej części pracy). Pogoń za zyskiem w warunkach XIX-wiecznej dziczy wymaga wreszcie pewnych pozytywnych cnót, np. odwagi. Na stronach O demokracji w Ameryce czytamy: „Trudno opisać łapczywość, z jaką Amerykanin rzuca się na ten wielki dar fortuny. W pogoni za nim gotów stawić czoło indiańskim strzałom i nieznanym chorobom, zamieszkać w niebezpiecznej ciszy lasów i wśród dzikich zwierząt. Namiętność silniejsza od miłości życia każe mu iść na pustkowia"59. Materializm łączy się jednak $\mathrm{z}$ wieloma innymi, negatywnymi przywarami, co wydaje się przesądzać o sceptycznym stosunku Francuza względem tej postawy.

\footnotetext{
A. de Tocqueville, O demokracji..., dz. cyt., s. 248.

Tamże, s. 50.

J. Baszkiewicz, Wstęp, dz. cyt., s. 19.

P. Śpiewak, Alexis de Tocqueville: demokracja..., dz. cyt., s. 8.

59 A. de Tocqueville, O demokracji..., dz. cyt., s. 210.
} 


\subsection{Przywary towarzyszące materializmowi: egoizm, indywidualizm, konformizm}

Gertrude Himmelfarb w swoim komentarzu do Raportu o pauperyzmie określa pracę francuskiego filozofa mianem „serii paradoksów" ${ }^{\circ 0}$. Nie tylko to dziełko Tocqueville’a dostarcza paradoksów. Za taki można uznać zestawienie w jego rozważaniach indywidualizmu i konformizmu - przeciwstawnych wydawałoby się tendencji, i przypisanie ich jednoczesnej obecności obserwowanym przez niego społeczeństwom demokratycznym ${ }^{61}$. Obydwie cechy jawią się w myśli Francuza jako wady, źródeł obydwu poszukuje on w równości możliwości, obydwie łączą się w pewien sposób z postawą materialistyczną.

Egoizm jest punktem wyjścia komentowanego autora dla refleksji odnośnie do indywidualizmu . Dla Tocqueville’a oznacza on „namiętną i przesadną miłość własną", przez którą człowiek najbardziej interesuje się sobą samym. Egoizm jest uczuciem, nie jest wynikiem „błędów umysłu”62. Dla Amerykanów egoizm stanowi niemal "teorię społeczną i filozoficzną"63. Przykładem „zimnego egoizmu” jest obojętne zachowanie Amerykanów względem śpiącego przy drodze umierającego Indianina ${ }^{64}$, ale także skupienie całej swojej uwagi na obowiązkach domowych, przy zaniechaniu zainteresowania sprawami publicznymi („nierozumny egoizm” ${ }^{65}$. „Nabożnym egoizmem” charakteryzuje się żona brata Tocqueville’a, którą nazywa on „najlepszą kobietą i najgorszą obywatelką"66. Egoizm przenika relacje rodzinne - przez niego odchodzi w zapomnienie pojęcie rodu, w zasięgu wzroku pozostają tylko żyjący, bliscy członkowie rodziny ${ }^{67}$; może on cechować nie tylko ludzi, ale też podejmowane przez nich przedsięwzięcia, np. partie polityczne ${ }^{68}$.

${ }^{60}$ G. Himmelfarb, Kto się ośmieli i pozwoli ubogiemu umrzeć z głodu, w: A. de Tocqueville, Raport o pauperyzmie, dz. cyt., s. 73.

${ }_{61}$ Zob. L. Joseph Hebert, Jr., Individualism and Intellectual Liberty in Tocqueville and Descartes, „The Journal of Politics” 2007 May, Vol. 69, No. 2, s. 525-527.

62 A. de Tocqueville, O demokracji..., dz. cyt., s. 339.

63 Tamże, s. 371.

${ }^{64}$ Tenże, Piętnaście dni..., dz. cyt., s. 11-12.

65 Tenże, $O$ demokracji..., dz. cyt., s. 429.

66 Tenże, Wspomnienia, dz. cyt., s. 48.

${ }_{67}$ Tenże, $O$ demokracji..., dz. cyt., s. 63.

68 Tamże, s. 137. Zdaniem Francuza egoizm jest właściwy małym partiom, bowiem te duże mogą żywić prawdziwe przekonania polityczne, mogą być inspirowane wielkimi celami. 
„Egoizm jest wadą starą jak świat i nie łączy się z jakimiś określonymi formami społecznymi. Indywidualizm ma źródło $\mathrm{w}$ demokracji i rośnie $\mathrm{w}$ miarę rozwoju równych możliwości" ${ }^{69}$ - pisze francuski filozof. Egoizm jest więc uniwersalny, zaś indywidualizm jest pokłosiem demokracji. Egoizm jest groźny dla wszelkich cnót - zarówno prywatnych (vide przykład umierającego Indianina), jak i publicznych (ilustracja żony Edwarda de Tocqueville'a), z kolei indywidualizm uderza raczej $w$ tę drugą grupę. K. Kędziora wiąże komentowane rozumienie indywidualizmu z prywatyzacją życia, zajęciem się dobrobytem, wycofaniem $\mathrm{z}$ życia publicznego ${ }^{70}$. Sam Tocqueville, porównując demokrację z ustrojem arystokratycznym, obserwuje:

Ludzie XVIII w. nie znali tej namiętności do dobrobytu materialnego, która prowadzi do niewoli, namiętności leniwej i uporczywej, łączącej się często z cnotami domowemi, dopuszczającej uczciwość, lecz nieznoszącej heroizmu, wyrabiającej przyzwoitych ludzi, lecz tchórzliwych obywateli ${ }^{71}$,

co oddaje doskonale istotę Tocqueville'owskiego rozumienia indywidualizmu oraz jego związku z materializmem. Niemniej, amerykańska demokracja stwarza instrumenty walki $\mathrm{z}$ tak pojmowanym indywidualizmem. Powszechne są kolektywne przedsięwzięcia ze słynnym (i zadziwiającym w oczach Francuza) przykładem zaprzysiężenia abstynencji przez 100 tysięcy osób; gminy czy sądy przysięgłych są szkołami wspólnotowości, o czym będzie mowa w dalszej części pracy. Demokracja jest więc polem ścierania się przeciwstawnych tendencji.

Indywidualizm występuje równolegle do tendencji uniformizacyjnych, konformizmu społecznego. Tocqueville kreśli obraz amerykańskiego społeczeństwa, w którym wszyscy ludzie są do siebie podobni, kierowani tymi samymi celami (dobrobytem materialnym). Podobieństwo dotyczy aspektów zewnętrznych ubioru czy języka, ale też tych głębszych - umysłowości ${ }^{72}$, obyczajów. Obejmuje ono zarówno mieszkańców miast, jak i zasiedlających pustkowia pionierów ${ }^{73}$. Francuz z zaskoczeniem przyjmuje fakt, że różnice między mieszkańcami nawet

\footnotetext{
69 Tamże, s. 339.

70 K. Kędziora, Alexis de Tocqueville o egzystencjalnym..., dz. cyt., s. 48-49.

71 A. de Tocqueville, Dawne rzady a rewolucja, przeł. W.M. Kozłowski, Wydawnictwo Vis-à-vis Etiuda, Kraków 2019, s. 98.

72 Jeden z rozdziałów $O$ demokracji w Ameryce poświęcony jest „metodzie filozoficznej Amerykanów (A. de Tocqueville, O demokracji..., dz. cyt., s. 271-274).

73 A. de Tocqueville, Piętnaście dni..., dz. cyt., s. 13.
} 
najodleglejszych od siebie stanów są niewielkie, podczas gdy we Francji mogły być bardzo duże nawet w przypadku sąsiadujących geograficznie regionów oddzielonych zaledwie rzeką (pisze o Bretanii i Normandii) ${ }^{74}$. Porównania francuskiego filozofa mają w tym zakresie również charakter historyczny, co podkreśla uniformizujący wymiar demokracji. Wskazuje on, że w społeczeństwach arystokratycznych poszczególne klasy społeczne różniły się od siebie, ale także członkowie w ramach tych klas byli różni - mieli „odmienne poglądy, uczucia, uprawnienia, obyczaje, swoje własne życie”, „odmienne namiętności, idee, zwyczaje, upodobania"75. Nostalgię za czasami przeddemokratycznymi daje się wyczuć w passusie:

Patrzę na te nieprzebrane tłumy złożone z istot podobnych do siebie, z których żadna nie przekracza granic narzuconych wszystkim. To powszechne ujednolicenie zasmuca mnie i przejmuje obawą i niemal skłonny jestem żałować społeczeństwa, którego już nie $\mathrm{ma}^{76}$.

Studiując przyczyny konformizmu, Tocqueville wskazuje na presję większości. „Tyrania większości” nie dotyczy jedynie sfery politycznej, ale objawia się również na innych płaszczyznach życia społecznego - prowadzi do standaryzacji norm moralnych, estetyki. Poddanie się temu nie jest nawet odczuwane jako zniewolenie, mimo że nim jest ${ }^{77}$. Presja większości jest zdaniem Francuza skuteczniejsza nawet niż hiszpańska inkwizycja, ta ostatnia nie potrafiła przeszkodzić obiegowi antyreligijnych wydawnictw, co stało się dziełem opinii w Stanach Zjednoczonych ${ }^{78}$.

Konformizm, którego obawia się Tocqueville, nie jest dążeniem do zrównania się z najlepszymi, nie prowadzi do ogólnego podwyższenia standardów estetycznych, moralnych czy umysłowych. Prowadzi on raczej do zdominowania życia społecznego przez przeciętność, przez którą brakuje wielkich celów, wielkich ambicji, wielkich talentów; wiedza jest powierzchowna, a pragnienia płytkie. Może to ostatecznie doprowadzić do zastoju na wielu płaszczyznach ${ }^{79}$. Rozumia-

\footnotetext{
74 A. de Tocqueville, O demokracji..., dz. cyt., s. 130.

75 Tamże, kolejno s. 369 i 406.

76 Tamże, s. 481.

77 J. Baszkiewicz, Wstęp, dz. cyt., s. 15.

78 A. de Tocqueville, O demokracji..., dz. cyt., s. 196.

79 Podobne obawy żywi Ortega y Gasset (Bunt mas, s. 114 i n.), z kolei Daniel Choi argumentuje, że materializm może pobudzać kreatywność na polu duchowym, etycznym, estetycznym, chociaż
} 
ny w ten sposób konformizm z pewnością kontrastuje z indywidualizmem w potocznym znaczeniu tego słowa. Jeśli jednak indywidualizm utożsamimy z prywatyzacją życia i oderwaniem od spraw publicznych, to kontrast i paradoksalność ich współwystępowania nie okażą się aż tak znaczące.

\section{Wychowanie}

\subsection{Uwagi ogólne}

Dotychczasowe rozważania ujawniły co najmniej dwa miejsca, w których postawa materialistyczna łączy się z problemem wychowania. Wskazano, że potrzeby drugorzędne wynikają ze „zwyczaju i wychowania” oraz to, że Tocqueville wyżej niż materializm ceni religię jako mechanizm porządkowania ludzkiego życia. W dalszej części pracy przyjmuję szeroką definicję wychowania, która obejmuje takie instrumenty socjalizacji jak edukacja formalna, wpajanie cnót oraz wychowanie religijne. Jak zauważa Russel Kirk, dla Tocqueville’a edukacja i religia są środkami zapobiegania wadom demokracji ${ }^{80}$, do których zalicza się postawa materialistyczna. Uzasadnia to przyjęty zakres rozważań. Zaznaczyć jednak trzeba, że francuski filozof nieco inaczej pojmuje wychowanie. Opiewając walory amerykańskiej demokracji, pisze: „Tak może być wszędzie, pod warunkiem wszakże, by wykształcenie, które oświeca, szło w parze z wychowaniem, które wpaja obyczaje" ${ }^{81}$. Odróżnia on zatem wychowanie służące wpojeniu obyczajów od edukacji formalnej służącej wpojeniu wiedzy. Zaznaczyć przy tym należy, że „obyczaje” w rozumieniu Francuza to „cały system moralny i intelektualny stan społeczeństwa”. Utożsamia on obyczaje z łacińskim mores ${ }^{82}$, czyli etymologicznym źródłem dzisiejszego pojęcia „moralność”. W dalszej części tego samego rozdziału O demokracji $w$ Ameryce Tocqueville wprost kojarzy edukację, wychowanie i religię, jako rzutujące łącznie na wykształcenie obyczajów:

mający tego dowodzić przykład reklam wielkich korporacji nie wydaje się przekonujący (Unprophetic Tocqueville, dz. cyt., s. 177).

80 R. Kirk, Konserwatywny umysł. Od Burke’a do Eliota, tłum. A. Wincewicz-Price, J. Price, Ośrodek Myśli Politycznej, Kraków 2017, s. 232, 235.

81 A. de Tocqueville, O demokracji..., dz. cyt., s. 218.

82 Tamże, s. 212-213. 
Demokratyczne zasady przeniknęły tu do codziennego życia i do poglądów obywateli i można je odnaleźć zarówno w najdrobniejszych przejawach życia społecznego, jak i w prawach. Właśnie na wschodzie najbardziej udoskonalano oświatę i wychowanie, a religia została w najpełniejszy sposób skojarzona $\mathrm{z}$ wolnością. Te nawyki, te przekonania, te formy życia, ta wiara, czymże są jeśli nie obyczajami ${ }^{83}$.

Pogląd, że człowiek może zostać wychowany, świadczy o pewnym optymizmie antropologicznym Tocqueville'a ${ }^{84}$, którego - mimo wielu wniosków łączących obydwu autorów- nie sposób doszukiwać się np. u Ortegi y Gasseta czy innych konserwatystów. Możliwość doskonalenia się - a do tego zmierza wychowanie - jest dla Francuza czynnikiem odróżniającym człowieka od zwierzą ${ }^{85}$. Tocqueville przestrzega, by wychowanie następowało „od kołyski”, bowiem już na najwcześniejszych etapach życia człowiek nabywa zalążki nawyków czy namiętności, które ujawniają się w dorosłym życiü ${ }^{86}$. W optyce Francuza istotną rolę w wychowaniu odgrywa autorytet, który jest „niezbędny” w życiu moralnym $\mathrm{i}$ intelektualnym. Kategoria autorytetu wiąże się z wolnością, ale wbrew potocznym intuicjom autorytet nie jest jej zaprzeczeniem, lecz warunkiem jej zaistnienia ${ }^{87}$. Autorytet służy wsparciem wobec konieczności rzetelnego rozstrzygania natłoku pojawiających się w życiu dylematów, których przeciętny człowiek nie byłby w stanie samodzielnie rozwiązywać ${ }^{88}$.

Wychowanie może służyć zwalczeniu efektów indywidualizmu. Na tej płaszczyźnie francuski myśliciel obserwuje różnicę między podejściem Amerykanów, u których wychowanie ukierunkowane jest społecznie, i Europejczyków, którzy koncentrują się na życiu prywatnym. Wynika z tego odmienny kierunek przenikania nawyków z obydwu sfer życia - w Europie zasady życia prywatnego kolonizują sferę publiczną, w Stanach Zjednoczonych do życia prywatnego przenosi się nawyki sfery publicznej ${ }^{89}$.

\footnotetext{
Tamże, s. 221.

Zob. A. Plichta, Równość i demokracja..., dz. cyt., s. 267.

A. de Tocqueville, O demokracji..., dz. cyt., s. 292.

Tamże, s. 48.

Zob. L. Joseph Hebert Jr., Individualism..., dz. cyt., s. 525-526.

Zob. A. de Tocqueville, O demokracji..., dz. cyt., s. 276. Obserwacja ta nie obiega od wniosków współczesnych autorów, zob. S. Gałkowski, Czy autorytet niszczy nasza autonomię?, „Filozofuj!” 2017, nr 5(17), s. 9-11.

89 A. de Tocqueville, $O$ demokracji..., dz. cyt., s. 218.
} 
Ten ostatni wniosek prowadzi do kwestii roli wykształcenia w demokracji. Jak zauważa Sylwia Bykowska, Tocqueville już we wstępie swojego opus magnum mówi tonem pedagoga o „wychowaniu demokracji” czy „oczyszczaniu jej obyczajów" ${ }^{\prime 90}$. Według francuskiego myśliciela funkcjonowanie demokracji - mimo oparcia na prostych zasadach - „zakłada istnienie bardzo cywilizowanego i bardzo oświeconego społeczeństwa" ${ }^{\text {"11 }}$, wykształcenie jest formą ochrony przed despotyzmem, który łatwo zbudować na ludzkich instynktach, ogarniających niewykształconych ${ }^{92}$. Komentowany autor podkreśla jednak, że tym, co różni go od oświeceniowych ekonomistów (wymienia Quesnay’a i Turgota), jest to, że obok konieczności wychowania i edukacji widzi on potrzebę funkcjonowania określonego systemu instytucjonalnego, zabezpieczeń systemowych przeciw nadużywaniu władzy ${ }^{93}$.

Z perspektywy Francuza wychowawczą funkcją nie są obarczone wyłącznie szkoły. Gminy (zgromadzenia mieszkańców danej jednostki administracyjnej), stowarzyszenia oraz sądy przysięgłych są dla niego „szkołami demokracji”. O instytucjach gminnych Tocqueville pisze, że „są dla wolności tym, czym dla nauki szkoły podstawowe" ${ }^{94}$. Stowarzyszenia są szkołami wspólnotowości, kooperatywnego przeciwdziałania moralnemu złu, a niekoniecznie tylko przedsięwzięciami handlowymi ${ }^{95}$. W jego rozważaniach szczególną rolę odgrywają sądy przysięgłych, w których udział ma uczyć obywateli odpowiedzialności za własne decyzje, a także odwagi cywilnej. Odrywając zainteresowanie człowieka od wyłącznie własnych spraw, udział w sądownictwie przeciwdziała egoizmowi. Co więcej, sądy przysięgłych pozwalają obywatelom stykać się z osobami bardziej wykształconymi i światłymi ${ }^{96}$. Pożądany model wychowania ma więc w optyce francuskiego myśliciela rozproszony charakter - biorą $\mathrm{w}$ nim udział różne podmioty i instytucje, filozof nie bagatelizuje jednak roli tradycyjnego szkolnictwa.

\footnotetext{
S. Bykowska, Wspólnota obywateli..., dz. cyt., s. 199.

A. de Tocqueville, O demokracji..., dz. cyt., s. 164.

Tamże, s. 456.

A. de Tocqueville, Dawne rzady..., dz. cyt., s. 124.

Tenże, O demokracji..., dz. cyt., s. 71.

Tamże, s. 149.

Tamże, s. 205-206.
} 


\subsection{Edukacja formalna}

Pisząc O demokracji w Ameryce, Tocqueville był pod ogromnym wrażeniem oświecenia Amerykanów. Wspomina on o przepisach regulujących obowiązek szkolny, które w czasie jego podróży po Stanach Zjednoczonych funkcjonowały na Starym Kontynencie w zasadzie jedynie w krajach niemieckojęzycznych. Francja ani Anglia nie wprowadziły jeszcze wówczas obowiązku szkolnego. Filozof zwraca uwagę na niezwykle niski poziom analfabetyzmu w Ameryce (wynikający z powszechności podstawowego wykształcenia), ale również na to, że społeczeństwo amerykańskie ubogie jest w uczonych ${ }^{97}$. Stanowi to przykład opisywanej wyżej skłonności do przeciętności. Niemniej na komentowanej płaszczyźnie owa przeciętność budzi uznanie Tocqueville’a - średni poziom wykształcenia Amerykanów jest bowiem wyższy niż ten u jego rodaków. Wskazuje on, że podniesienie poziomu wykształcenia w całym społeczeństwie ponad pewien standard jest niemożliwe; trudne do wyobrażenia jest społeczeństwo, w którym wszyscy ludzie będą wykształceni, tak jak to, w którym wszyscy będą bogaci ${ }^{98}$.

Francuz nie przecenia formalnego wykształcenia - dostrzega, że wpojenie umiejętności czytania i pisania nie jest wystarczające dla ukształtowania wartościowych obywateli; dostrzega on wagę doświadczenia ${ }^{99}$. Jeśli skonfrontujemy ten wniosek z językiem, którym Francuz opisuje ludzkie przywary (instynkty, namiętności, żądze), stanie się oczywiste, że wysiłki wychowawcze należy skierować na warstwę duchową czy emocjonalną człowieka, a nie jedynie jego stronę intelektualną. Według Tocqueville’a amerykańską edukację cechuje praktyczne nastawienie, nie może zatem dziwić, że środowisko to zrodziło piewców praktycznego nauczania takich jak John Dewey. Z aprobatą Francuza spotyka się to, że w Ameryce kształceniu podlegają też kobiety ${ }^{100}$, co nie było oczywiste w jego ojczyźnie.

Pomimo dostrzeżenia przez francuskiego filozofa wagi wykształcenia, w 1848 roku wystąpił on przeciw poprawce francuskiej konstytucji, która zakładała obowiązek państwa w dostarczeniu „niezbędnego wszystkim ludziom wykształcenia”. Powodem krytyki był nadmierny socjalizm tego rozwiązania, obawa, że

\footnotetext{
Tamże, s. 64.

Tamże, s. 157.

Tamże, s. 218.

Tamże, s. 383.
} 
państwo stanie się największym, o ile nie jedynym przedsiębiorcą ${ }^{101}$, a rozwiązanie to zdławi przedsiębiorczość i odpowiedzialność obywateli. Stanowisko to nie było jednak sprzeczne $\mathrm{z}$ uznaniem prezentowanym względem rozwiązań amerykańskich - powszechność tamtejszego szkolnictwa nie wynikała z odgórnej ingerencji państwa, lecz działania wielu oddolnych, prywatnych bądź wymaganych przepisami stanowymi inicjatyw. Niebagatelną rolę w rozwoju amerykańskiego szkolnictwa odegrały kościoły ${ }^{102}$; nie może więc dziwić, że dla Francuza „oświata i mądrość są dziećmi moralności i religii"103.

\subsection{Cnoty}

Pojęcie cnoty występuje w myśli Tocqueville’a w dwóch znaczeniach. Po pierwsze jako sprzężone z poszczególnymi cnotami, odnoszącymi się do konkretnych dziedzin życia - np. odwaga czy przedsiębiorczość, po drugie jako cnota w znaczeniu ogólnym ${ }^{104}$. To ostatnie znaczenie pojawia się np. we frazie: „Wyjąwszy pojęcie cnoty, nie znam piękniejszej idei jak idea praw człowieka"105, która oddaje przywiązanie Francuza do komentowanej kategorii. Francuski myśliciel odróżnia cnoty prywatne od cnót publicznych, ideałem jest dla niego człowiek łączący obydwie te grupy, czemu daje wielokrotnie wyraz we Wspomnieniach, charakteryzując osoby, z którymi się stykał106.

Kategoria cnoty jest głęboko związana z wychowaniem. Cnoty są uzupełnieniem wykształcenia formalnego; nie da się ich wpoić przy pomocy formalnego kształcenia - nie zależą od umiejętności czytania czy pisania ${ }^{107}$. Pojawienie się i utrzymanie cnót wymaga czasu, doświadczenia i praktyki, nie polega zaś na wyłącznie intelektualnym przyswojeniu określonych zasad. Paweł Marczewski, komentując pojęcie cnót publicznych w myśli Tocqueville’a, stwierdza, że autor ten podąża „tropem republikanów, kiedy broni wizji cnoty publicznej jako

\footnotetext{
P. Śpiewak, Alexis de Tocqueville: demokracja..., dz. cyt., s. 31.

02 Zob. J.W. Ceaser, P.J. McGuinn, Civic education reconsidered, „The Pubic Interest” 1998 Fall, s. 97 in.

103 A. de Tocqueville, O demokracji..., dz. cyt., s. 159.

104 Zob. M. Tracz-Tryniecki, Myśl polityczna i prawna..., dz. cyt., s. 126.

105 A. de Tocqueville, O demokracji..., dz. cyt., s. 181.

106 Zob. tenże, Wspomnienia, s. 46, gdzie o panu Dufaure pisze „Jego cnoty prywatne i cnoty publiczne, a posiadał i te, i tamte (i to znaczne), nie chadzały równym krokiem, pierwsze wyprzedzały zawsze drugie".

107 Zob. M. Tracz-Tryniecki, Myśl polityczna i prawna..., dz. cyt., s. 129.
} 
praktyki politycznej, a nie umiejętności odczytywania abstrakcyjnych reguł sprawiedliwości" 108 .

Francuz odróżnia cnoty od manier, nie utożsamia ich również $\mathrm{z}$ honorem. Dostrzega on jednak, że - podobnie jak maniery oraz rozumienie honoru - w demokracji zmienia się pojęcie cnót oraz ich wartościowanie. Zdaniem komentowanego myśliciela $\mathrm{w}$ średniowieczu najwyżej cenione były cnoty wojenne, a wśród nich odwaga, w przeciwieństwie do starożytności - ze względu na zależności feudalne - nie funkcjonowało natomiast pojęcie patriotyzmu ${ }^{109}$. To ostatnie odradza się w demokracji, jednak ma inny wymiar niż w starożytności, jest bardziej związane z interesem prywatnym i dopiero połącznie tego interesu ze sprawami publicznymi jest podstawą demokratycznego patriotyzmu. Z kolei odwaga zyskuje nowe formy - odrywa się od wyłącznie militarnego wymiaru (chociaż starcia z Indianami mogą być przykładem tego aspektu odwagi), zyskuje natomiast wymiar gospodarczy, łączy się ze skłonnością do podejmowania ryzykownych przedsięwzięć w celu pomnożenia zysku ${ }^{110}$. Tocqueville wskazuje, że demokracja sprzyja cnotom umiarkowanym, co po raz kolejny przypomina o inklinacji tego ustroju do przeciętności. W demokracji za istotne uchodzi utrzymanie stabilności, ładu społecznego, co powoduje rozkwit sprzyjających temu cnót.

Materializm - który dawniej nazwano by chciwością - zaczyna w amerykańskim społeczeństwie uchodzić za cnotę. Francuz krytykuje jednak ten „cnotliwy materializm", podnosząc, że odrywa on od poszukiwania prawdziwej cnoty; nie można połączyć cnoty z nastawieniem konsumpcyjnym ${ }^{111}$. Materializm wpływa więc na cnotę, lecz wychowanie może zwalczać materializm poprzez wpajanie właściwych cnót.

\subsection{Religia}

Tocqueville nie był osobą wierzącą. Już jako młody człowiek za największe utrapienia ludzkości uważał chorobę, śmierć i wątpliwości (w języku angielskim jako aliteracja: disease, death, doubt $)^{112}$, przy czym te ostatnie odnosiły się do istnienia Boga. W liście do Artura de Gobineau z 2 października 1843 roku pisze: „Ja sam

108 P. Marczewski, Uczynić wolność..., dz. cyt., s. 105.

109 A. de Tocqueville, $O$ demokracji..., dz. cyt., s. 410-411.

110 Tamże, s. 413.

111 M. Tracz-Tryniecki, Myśl polityczna i prawna..., dz. cyt., s. 130.

112 J.P. Mayer, Alexis de Tocqueville. A biographical study in political science, Harper \& Brothers, New York 1960, s. 3. 
nie jestem wierzący (nie mówię tego oczywiście, by się tym chwalić), ale nawet jako człowiek niewierzący nigdy nie mogłem czytać Ewangelii bez głębokiego wzruszenia"113, i zdanie to dobrze oddaje stosunek Francuza do religii. Nie był to stosunek wojującego ateisty, lecz człowieka dostrzegającego głębokie społeczne znaczenie wiary. Tocqueville szczególnie wysoko cenił chrześcijaństwo w jego moralnym, a niekoniecznie instytucjonalnym wymiarze ${ }^{114}$.

Francuz podkreśla związek między powstaniem Stanów Zjednoczonych a religią: „Społeczeństwom angloamerykańskim początek dała religia, i nie należy o tym nigdy zapominać” oraz jej ciągle aktualne znaczenie: „W Stanach Zjednoczonych religia spleciona jest więc ze wszystkimi narodowymi zwyczajami i ze wszystkimi uczuciami, jakie ludzie żywią wobec ojczyzny. To nadaje jej szczególną siłę"115. W opowiadaniu Piętnaście dni w pustkowiu Tocqueville przytacza obraz pionierów gromadzących się na wieść o przybyciu księdza w rejon ich zamieszkania. Potrafią oni oderwać się na kilka dni od codziennych obowiązków, by na „świeżym powietrzu, pod koronami drzew” oddawać się praktykom religijnym $^{116}$. W Ameryce filozof nie zaobserwował nienawiści przeciw religii, która towarzyszyła jego zdaniem uczestnikom rewolucji francuskiej ${ }^{117}$.

Dla Francuza religia stoi u podstaw moralności, zaś ta jest warunkiem wolności. Nie zgadza się on $\mathrm{z}$ poglądem stawiającym religię $\mathrm{w}$ opozycji do wolności ${ }^{118}$. Słabnięcie znaczenia religii przekłada się - jego zdaniem - na zepsucie obyczajów oraz „zanik moralnego pojmowania praw”119. W myśli Francuza prezentowana jest również teza, że to chrześcijaństwo, upowszechniając jako pierwsze ideę równości, otworzyło drogę rozwoju demokracji ${ }^{120}$. Wreszcie to właśnie za sprawą religii w Ameryce rozwija się tak pomyślnie szkolnictwo ${ }^{121}$. Tocqueville nie skupia się na historycznych aspektach budowania amerykańskiej oświaty, jednak ma rację, formułując takie twierdzenie ${ }^{122}$.

\footnotetext{
113 List do Artura de Gobineau z 17.11.1853 r., w: A. de Tocqueville, Listy, dz. cyt., s. 176.

114 K. Kędziora, Alexis de Tocqueville o egzystencjalnym..., dz. cyt., s. 37.

115 A. de Tocqueville, O demokracji..., dz. cyt., s. 273.

116 Tenże, Piętnaście dni..., dz. cyt., s. 24.

117 Tenże, Dawne rządy..., dz. cyt., s. 12.

118 Tenże, O demokracji..., dz. cyt., s. 34-35, 58.

119 Tamże, s. 182.

120 Zob. K. Kędziora, Alexis de Tocqueville o egzystencjalnym..., dz. cyt., s. 43.

121 A. de Tocqueville, O demokracji..., dz. cyt., s. 56.

122 Zob. M.S. Katz, A History of Compulsory Education Laws, Phi Delta Kappa Educational Foundation, Bloomington, Ind. 1976, No. 75, s. 11-13.
} 
Niezależnie od wskazanych zalet czy zasług religii, francuski filozof zwraca uwagę na jej rolę w walce $\mathrm{z}$ materializmem. Odbywa się to na dwa sposoby:

Trzeba przyznać bowiem, że równość, która jest dla świata dobroczynna, budzi jednak w ludziach, jak to zaraz wyjaśnię, bardzo niebezpieczne instynkty - izolując ich mianowicie od siebie, sprawia, że każdy zajmuje się wyłącznie sobą. Wpaja ludziom nieopanowane pragnienie korzyści materialnych. Największą zaletą religii jest to, iż wzbudza u ludzi dwie przeciwne tendencje. Każda religia umieszcza przedmiot pragnień człowieka ponad dobrami ziemskimi i unosi jego duszę ku rejonom znacznie wyższym od świata zmysłowego. Ale każda religia narzuca również człowiekowi obowiązki wobec innych ludzi oraz, co za tym idzie, nie pozwala poświęcać zbyt wiele uwagi własnej osobie $^{123}$.

W cytowanym wyżej liście do Artura de Gobineau Tocqueville wyjaśnia z kolei, że relacja wiara-materializm może przebiegać także w drugą stronę. Nie tylko religia może wypierać postawę materialistyczną, ale też „kiedy ludzie tracą z oczu rozkosze niebiańskie, przywiązują się coraz bardziej do jedynych dóbr, jakie im pozostały: dóbr doczesnych. I pragną ich tym mocniej, że istnienie tamtych staje się niepewne"124. Nie oznacza to jednak, że z perspektywy Francuza to materializm musi zająć miejsce religii. W pracy Dawne rzady a rewolucja - traktując o wrogiej religii postawie rewolucjonistów francuskich - optymistycznie pokazuje, że miejsce wiary może zająć niemający nic wspólnego z egoizmem, skłaniający do poświęceń patriotyzm ${ }^{125}$.

\section{Konkluzje}

Na stronach $O$ demokracji $w$ Ameryce Tocqueville relacjonuje swoje spotkanie z marynarzem, który na pytanie: „dlaczego statki są w jego kraju tak budowane, że mają krótki żywot", odpowiada, że postęp w sztuce żeglarskiej jest tak dyna-

\footnotetext{
A. de Tocqueville, O demokracji..., dz. cyt., s. 287.

124 List do Artura de Gobineau z 17.11.1853 r., w: A. de Tocqueville, Listy, dz. cyt., s. 177. W podobnym kierunku zmierzają rozważania Maxa Webera zawarte w słynnej pracy Etyka protestancka a duch kapitalizmu (zob. M. Weber, Etyka protestancka a duch kapitalizmu. Protestanckie „sekty” a duch kapitalizmu, przeł. B. Baran, P. Miziński, Aletheia, Warszawa 2010, s. 126-127). 
miczny, że statki stają się bezużyteczne już po kilku latach ${ }^{126}$. Francuz przytacza tę anegdotę dla ukazania obecnego u Amerykanów przekonania o nieograniczonej zdolności człowieka do doskonalenia się. Wydaje się, że przez przypadek odkrywa on również jedną z zasad rządzących współczesną gospodarką, rzutującą i jednocześnie będącą warunkowaną przez ogarniający społeczeństwa konsumpcjonizm. Chodzi o zasadę takiego tworzenia produktu, by nie był trwały, by można było go w nieodległej przyszłości zastąpić nowym.

W innym miejscu francuski myśliciel pisze: „Kiedy jakiś mieszkaniec Indii ogranicza swoje wydatki i zmniejsza konsumpcję, cierpi na tym angielski fabrykant"127, oddając wiernie, blisko dwa wieki temu, istotę współczesnego globalizmu.

Przytoczone przykłady w swojej zewnętrznej warstwie potwierdzają profetyczne zdolności komentowanego autora - trafnie przewidział on poszczególne procesy czy zjawiska. Przewidywania te są jeszcze cenniejsze, jeśli dostrzeżemy ich ogólny wymiar - obydwa dotyczą wzrostu znaczenia ekonomii w życiu człowieka. Komentowany w artykule problem materializmu jest tylko jednym z aspektów tego zjawiska. Wzrost znaczenia ekonomii zderza się z republikańskimi założeniami stojącymi u podstaw myślenia Tocqueville'a ${ }^{128}$. Koliduje on z wagą, którą Francuz przykłada do życia publicznego i udziału obywateli w tym życiu. Jak zauważa Raymond Aron, Francuz „nie godzi się na podporządkowanie polityki gospodarce" 129 , ale też - o czym przekonują chociażby rozważania dotyczące stosunku ludzi demokracji do rodziny - dostrzega szkodliwość podporządkowania gospodarce sfery prywatnej. Podobnie jak inni autorzy wpisujący się w nurt myśli republikańskiej ubolewa on nad tym, że wartości polityczne tłumaczone są na język wartości ekonomicznych ${ }^{130}$.

126 A. de Tocqueville, O demokracji..., dz. cyt., s. 293.

127 Tenże, Raport o pauperyzmie, dz. cyt., s. 52. Kulturowe aspekty globalizacji opisuje on na stronach O demokracji w Ameryce: „Ród ludzki staje się jednolity. Na całym świecie pojawiają się te same sposoby działania, myślenia i odczuwania" (tamże, s. 407).

128 Próby zakwalifikowania myśli Tocqueville’a są przedmiotem niekończących się kontrowersji. Marek Tracz-Tryniecki (Myśl polityczna i prawna..., dz. cyt., s. 377) rozpatruje takie wątki interpretacyjne jak liberalizm, republikanizm, konserwatyzm czy katolicka nauka społeczna. Paweł Marczewski poszukuje z kolei wątków republikańskich w myśli Francuza, rezultatem czego jest wniosek o przynależności Tocqueville’a do „hybrydowej tradycji” (tenże, Uczynić wolność..., dz. cyt., s. 28).

129 R. Aron, Esej o wolnościach, tłum. M. Kowalska, Fundacja Aletheia, Warszawa 1997, s. 37.

130 Zob. K. Ptaszyk, Pochwała cnoty politycznej wedtug Alexisa de Tocquevillea i Hanny Arendt, „Zeszyt Studencki Kół Naukowych Wydziału Prawa i Administracji UAM” 2011, nr 1, s. 135. 
Myśl francuskiego filozofa nie jest jednak pozbawiona ograniczeń, które niekoniecznie muszą wynikać z przyjmowanych przez niego republikańskich ideałów. Nie może budzić wątpliwości, że pewnym obciążeniem była pozycja arystokraty, z której tworzył. Nie do pojęcia była dla niego pogoń za dostatkiem, co łatwo wyjaśnić tym, że sam nie musiał nigdy brać w niej udziału. Tocqueville widział, że dobrobyt nie robi wrażenia na arystokracji, nie potrafił jednak spojrzeć na inne klasy społeczne w sposób pozbawiony arystokratycznego pryzmatu ${ }^{131}$. $\mathrm{Z}$ jednej strony wpływa to na - chwilami zbyt kategoryczną - ocenę materializmu, z drugiej, być może pozwala spojrzeć z zewnątrz i właściwie zlokalizować problem - biorący udział w dążeniu do bogactwa przedstawiciel klasy średniej mógłby nie zdobyć się na porównywalną przenikliwość.

Wydaje się, że diagnozy Francuza w związku z wychowawczą i przeciwdziałającą materializmowi rolą religii, przynajmniej ze współczesnej perspektywy, również należy podać $\mathrm{w}$ wątpliwość. $\mathrm{W}$ dobie powszechnej sekularyzacji czy - jak interpretują niektórzy badacze - prywatyzacji religii, „namiętność do dobrobytu" triumfuje niestety nad duchowością lub z nią bezkolizyjnie koegzystuje. (Zalążki postępującej sekularyzacji powinny być dla wychowującego się w porewolucyjnej Francji filozofa łatwo dostrzegalne.) Wobec tego materializm - ziszczając obawy Francuza - kolonizuje wszystkie sfery życia, nie napotykając właściwej przeciwwagi. Rolę tej wydaje się współcześnie coraz śmielej odgrywać ekologia ${ }^{132}$.

Trudno zarzucać francuskiemu myślicielowi niedostrzeżenie narodzin tej dziedziny. Pisze on co prawda $\mathrm{z}$ wyraźnym uznaniem o amerykańskiej przyrodzie, ze zdziwieniem przyjmuje fakt, że pionierzy wolą pokazać mu most czy drogę, a nie piękno otaczających je drzew, ubolewa nad karczowaniem lasów ${ }^{133}$. Niemniej nie docenia on demograficznych prognoz Malthusa oraz nie dostrzega stojącego u podstaw współczesnej ekologii założenia o ograniczoności zasobów Globu. W trakcie jego podróży po Stanach Zjednoczonych zajmowały one wschód kontynentu, ale jeszcze za życia Tocqueville’a dotarły do wybrzeży Pacyfiku, co mogło skłaniać do refleksji na temat wyczerpalności zasobów. Niezależnie od tego, wskazać trzeba, że nawet współczesna ekologia często ulega postawie

\footnotetext{
131 Przypomina to słowa songu Bertolta Brechta Człowieku, jak masz żyć? w polskim przekładzie Romana Kołakowskiego: „Panowie, co skwapliwie nas uczycie, / czym różni się od łaski pańskiej grzech, / zarobić dajcie na uczciwe życie, / bo to ważniejsze od cnót boskich trzech".

133 A. de Tocqueville, Piętnaście dni..., dz. cyt., s. 16-17.
} 
materialistycznej. Nie chodzi przy tym tylko o skorumpowanie badaczy czy aktywistów ${ }^{134}$, dotykające każdej dziedziny, lecz o czynienie z prób ochrony środowiska kolejnego sposobu na łatwiejszą sprzedaż swoich produktów czy zjawisko tzw. greenwashingu. Obrazuje to trudność w zbudowaniu mocnej alternatywy dla postawy materialistycznej.

W tej sytuacji aktualna pozostaje cytowana przez tak różnych autorów jak Russell Kirk i Raymond Aron przepowiednia Tocqueville'a:

Kiedy próbuję sobie wyobrazić ten nowy rodzaj despotyzmu zagrażający światu, widzę nieprzebrane rzesze identycznych i równych ludzi, nieustannie kręcących się w kółko w poszukiwaniu małych i pospolitych wzruszeń, którymi zaspokajają potrzeby swojego ducha. Każdy z nich żyje w izolacji i jest obojętny wobec cudzego losu; ludzkość sprowadza się dla niego do rodziny i najbliższych przyjaciół; innych współobywateli, którzy żyją tuż obok, w ogóle nie dostrzega; ociera się o nich, ale tego nie czuje ${ }^{135}$.

\section{Bibliografia}

Aron R., Esej o wolnościach, przeł. M. Kowalska, Fundacja Aletheia, Warszawa 1997.

Baszkiewicz J., Wstęp, w: A. de Tocqueville, O demokracji w Ameryce, tłum. M. Król, Państwowy Instytut Wydawniczy, Warszawa 1976.

Bykowska S., Wspólnota obywateli w idei demokracji Alexisa de Tocqueville'a. Ameryka wzorem dla Europy, „Studia Gdańskie. Wizje i rzeczywistość” 2010, t. VII.

Ceaser J.W., McGuinn P.J., Civic education reconsidered, „The Pubic Interest” 1998 Fall, s. 84-103.

Choi D., Unprophetic Tocqueville. How Democracy in America Got the Modern World Completely Wrong, „The Independent Review” 2007, Vol. XII, No. 2 s. $165-178$.

\footnotetext{
134 Por. R. Scruton, Zielona filozofia. Jak poważnie myśleć o naszej planecie, przeł. J. Grzegorczyk, R.P. Wierzchosławski, Zysk i S-Ka, Poznań 2017.

135 A. de Tocqueville, O demokracji..., dz. cyt., s. 469.
} 
Gałkowski S., Czy autorytet niszczy nasza autonomię?, „Filozofuj!” 2017, nr 5(17), s. 9-11.

Himmelfarb G., Kto się ośmieli i pozwoli ubogiemu umrzeć z głodu, w: A. de Tocqueville, Raport o pauperyzmie, tłum. J. Strzelecka, Wydawnictwo Uniwersytetu Warszawskiego, Warszawa 2009.

Jackson T., Dobrobyt bez wzrostu. Ekonomia dla planety o ograniczonych możliwościach, tłum. M. Polakowski, Wydawnictwo Naukowe UMK, Toruń 2015.

Joseph Hebert Jr. L., Individualism and Intellectual Liberty in Tocqueville and Descartes, „The Journal of Politics” 2007, Vol. 69, No. 2, s. 525-537.

Katz M.S., A History of Compulsory Education Laws, Phi Delta Kappa Educational Foundation, Bloomington, Ind. 1976, No. 75.

Kędziora K., Alexis de Tocqueville o egzystencjalnym i społecznym znaczeniu religii, „Studia Philosophiae Christianae UKSW” 2014, nr 50/4, s. 31-55.

Kirk R., Konserwatywny umyst. Od Burke’a do Eliota, tłum. A. Wincewicz-Price, J. Price, Ośrodek Myśli Politycznej, Kraków 2017.

Marczewski P., Uczynić wolność nieuchronną. Wątki republikańskie w myśli Alexisa de Tocqueville'a, Wydawnictwo IFiS PAN, Warszawa 2012.

Mayer J.P., Alexis de Tocqueville. A biographical study in political science, Harper \& Brothers, New York 1960.

Ortega y Gasset J., Bunt mas, tłum. P. Niklewicz, Wydawnictwo Replika, Zakrzewo 2016.

Plichta A., Równość i demokracja w myśli Alexisa de Tocqueville’a, „Acta Erasmiana" 2013, tom V, s. 263-276.

Ptaszyk K., Pochwała cnoty politycznej wedtug Alexisa de Tocqueville’a i Hanny Arendt, „Zeszyt Studencki Kół Naukowych Wydziału Prawa i Administracji UAM" 2011, nr 1, s. 129-138.

Radkowski A., Co Tocqueville mówi nam o demokracji-spojrzenie z perspektywy ekonomicznej teorii polityki, „Societas et Ius” 2017, nr 6, s. 157-176.

Scruton R., Zielona filozofia. Jak poważnie myśleć o naszej planecie, tłum. J. Grzegorczyk, R.P. Wierzchosławski, Zysk i S-Ka, Poznań 2017.

Starego K., Projekt: Obywatel. Rzecz o społecznej kontroli, zarządzaniu zmysłowością i strategiach oczyszczania, w: Subsumcje edukacji, red. M. Chutorański, J. Moroz, O. Szwabowski, Wydawnictwo Naukowe Katedra, Gdańsk 2017. 
ŚpiewakP., Alexisde Tocqueville: demokracja, rewolucje, socjalizm, w: A. de Tocqueville, Raport o pauperyzmie, tłum. J. Strzelecka, Wydawnictwo Uniwersytetu Warszawskiego, Warszawa 2009.

Tocqueville A. de, Dawne rządy a rewolucja, tłum. W.M. Kozłowski, Wydawnictwo Vis-à-vis Etiuda, Kraków 2019.

Tocqueville A. de, Listy, tłum. B. Janicka, Społeczny Instytut Wydawniczy Znak, Kraków 1999.

Tocqueville A. de, O demokracji w Ameryce, tłum. M. Król, Państwowy Instytut Wydawniczy, Warszawa 1976.

Tocqueville A. de, Piętnaście dni w pustkowiu, tłum. R. Chymkowski, Polityka Spółdzielnia Pracy, Warszawa 2003.

Tocqueville A. de, Raport o pauperyzmie, tłum. J. Strzelecka, Wydawnictwo Uniwersytetu Warszawskiego, Warszawa 2009.

Tocqueville A. de, Wspomnienia, tłum. A.W. Labuda, Wydawnictwo Zakład Narodowy im. Ossolińskich, Wrocław 1987.

Tracz-Tryniecki M., Myśl polityczna i prawna Alexisa de Tocqueville, Księgarnia Akademicka, Kraków 2009.

Weber M., Etyka protestancka a duch kapitalizmu. Protestanckie „sekty” a duch kapitalizmu, tłum. B. Baran, P. Miziński, Aletheia, Warszawa 2010.

\section{Streszczenie}

Artykuł przedstawia podejście Alexisa de Tocqueville’a do materializmu pojmowanego jako pożądanie materialnego dobrobytu oraz możliwości przeciwdziałania temu zjawisku. Praca opisuje kontekst, w którym pojawia się materializm, oraz jego negatywne następstwa, w tym indywidualizm i konformizm. Wychowanie, w którym Tocqueville upatruje środka zaradczego przeciwko zdominowaniu społeczeństwa przez materializm, jest $\mathrm{w}$ artykule powiązane $\mathrm{z}$ edukacją formalną, rozwojem osobistych cnót oraz z religią. Autor artykułu formułuje pesymistyczne wnioski odnośnie do możliwości przeciwdziałania postawie materialistycznej we współczesnych społeczeństwach.

Słowa kluczowe: materializm, egoizm, indywidualizm, równość, demokracja, wychowanie, edukacja, religia 


\section{Summary}

\section{Materialism and Upbringing in the Thought of Alexis de Tocqueville}

The article presents Alexis de Tocqueville's approach to the problem of materialism as well as potential reactions to that phenomenon. The concept of materialism is understood in the article as the urge towards material wellbeing. The work explains the context of materialism's appearance and its negative consequences, including individualism and conformism. Upbringing, which is treated as a countermeasure against materialism, is connected with formal education, development of personal virtues and also with religion. The author provides pessimistic conclusions regarding the possibility of avoiding the state in which materialism prevails in modern societies.

Key words: materialism, egoism, individualism, equality, democracy, upbringing, education, religion 